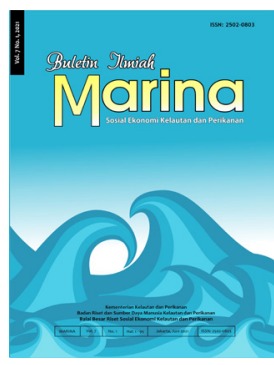

BULETIN ILMIAH MARINA

SOSIAL EKONOMI KELAUTAN DAN PERIKANAN

http://ejournal-balitbang.kkp.go.id/index.php/mra

p-ISSN: 2502-0803

e-ISSN: 2541-2930

Nomor Akreditasi: 10/E/KPT/2019

\title{
Analisis Margin Pemasaran Komoditas Tambak Air Payau Skala Tradisional Plus di Pasuruan, Jawa Timur
}

\section{Marketing Margin Analysis of Traditional Plus Scale Brackish- Water Commodities in Pasuruan, East Java}

\author{
Nasikh¹, Hadi Sumarsono', Joko Sayono², Mohd Al-ikhsan Ghazali ${ }^{3}$, \\ Yunani ${ }^{4}$, dan Lely Jayanti ${ }^{4}$ \\ 1Jurusan Ekonomi Pembangunan, Fakultas Ekonomi, Universitas Negeri Malang \\ Jln. Semarang Nomor 5, Malang, Jawa Timur, Indonesia \\ 2Jurusan Sejarah, Fakultas IImu Sosial, Universitas Negeri Malang \\ JIn. Semarang Nomor 5, Malang, Jawa Timur, Indonesia \\ ${ }^{3}$ Faculty of Islamic Civilization Universiti Teknologi Malaysia \\ Akademi Tamadun Islam, FSSK, UTM 54100, Kuala Lumpur, Malaysia \\ ${ }^{4}$ Lembaga Swadaya Masyarakat \\ H. Taman Jln. Nener Kalirejo, Kecamatan Bangil, Kabupaten Pasuruan, Jawa Timur, Indonesia \\ Diterima tanggal: 23 Mei 2020 Diterima setelah perbaikan: 6 Mei 2021 \\ Disetujui terbit: 30 Juni 2021
}

\begin{abstract}
ABSTRAK
Kabupaten Pasuruan merupakan salah satu produsen ikan budi daya tambak air payau skala tradisional plus terbesar di Jawa Timur, Indonesia. Sistem distribusi komoditas tambak tradisional plus yang menguntungkan sangat menentukan keberhasilan petambak dalam meningkatkan pendapatannya. Tujuan penelitian untuk mengetahui pola pemasaran komoditas tambak tradisional plus dan mengetahui margin pemasaran komoditas tambak tradisional plus di Kecamatan Bangil, Kabupaten Pasuruan. Penelitian ini dilakukan kurang lebih selama tiga tahun, antara bulan Mei 2017 sampai dengan Agustus 2020. Pengambilan sampel pada penelitian ini melalui teknik snowball sampling, yaitu sebanyak 35 petambak, 8 pedagang pengumpul, 7 pedagang besar, dan 5 pedagang pengecer. Data dianalisis secara deskriptif terhadap pola margin pemasaran dan kinerja pasar. Hasil penelitian menunjukkan ada lima pola margin pemasaran komoditas tambak tradisional plus, dan pola margin pemasaran yang ketiga dinilai efisien, karena jalur pemasarannya cukup pendek dan tidak mengurangi pendapatan petambak sehingga penerimaan pendapatan petambak lebih menguntungkan dibanding dengan pola margin pemasaran lainnya. Untuk itu, diperlukan kerja sama antara pemerintah daerah Kabupaten Pasuruan, petambak, dan pedagang agar sistem pemasaran ini lebih efisien sehingga pendapatan petambak tidak menurun.
\end{abstract}

Kata Kunci: marjin pemasaran; komoditas tambak; tradisional plus; kesejahteraan petambak; petambak

\section{ABSTRACT}

Pasuruan Regency is a lowland fish farming area and one of the greatest traditional plus fish farming in East Java, Indonesia. The profitable distribution system of traditional plus pond affect the successful of farmers to improve their income. This research aimed to formulate the marketing model and margin of traditional plus pond commodity in order to improve the welfare of fish farmers in Bangil Sub-District, Pasuruan Regency. This research was conducted for three years, from May 2017 until August 2020. Snowball sampling is selected to choose participants, they consisted of 35 fish farmers, 8 collector traders, 7 large traders, and 5 retailers. Data were analyzed descriptively to describe the 
marketing margin model and market performance. The results showed that there were five models of marketing margin of traditional plus ponds, and the third model would be the most efficient model because of its relatively short marketing path and no farmers' income were reduced. Therefore, the model offered more profitable income for the fish farmers than the other model. In addition, it is necessary to corporate among regional government, fish farmers, and traders for more efficient marketing system, and to avoid the decrease of fish farmers' income.

\section{Keywords: marketing margin; pond's commodities; traditional plus; fish farmers' welfare; fish farmer}

\section{PENDAHULUAN}

\section{Latar Belakang}

Sebagian besar wilayah Indonesia yang berupa perairan menjadikan Indonesia kaya akan sumber daya laut. Hal tersebut mengakibatkan berlimpahnya hasil perikanan di Indonesia. Produksi ikan tangkap di Indonesia memang lebih banyak jika dibandingkan dengan ikan budi daya, tetapi perikanan budi daya memiliki proyeksi produksi yang bagus dalam beberapa tahun ke depan. Saat ini Indonesia merupakan produsen perikanan budi daya terbesar keempat di dunia dan sektor ini harus tumbuh agar dapat memenuhi permintaan ikan di masa mendatang (Indonesia Climate Change Trust Fund [ICCTF], 2020). Hasil analisis mengindikasikan bahwa perikanan budi daya akan melampaui perikanan tangkap sebagai sumber utama ikan di Indonesia sebelum tahun 2030 (Phillips et al., 2016; Nguyen et al., 2018; Jayanti, 2020).

Keadaan geografis Kabupaten Pasuruan yang mayoritas merupakan dataran rendah membuat kabupaten ini unggul dalam sektor pertanian, tak terkecuali sektor perikanan. Selain unggul dengan perikanan tangkap, Kabupaten Pasuruan juga unggul dalam perikanan budi daya terutama tambak. Kabupaten Pasuruan merupakan salah satu produsen ikan budi daya tambak tradisional plus terbesar di Jawa Timur. Sampai akhir tahun 2018, produksi perikanan budi daya di Kabupaten Pasuruan mencapai 18.909,138 ton (Pemerintah Kabupaten Pasuruan, 2020). Jika dibandingkan dengan produksi perikanan budi daya tambak di Jawa Timur sebesar 219.186,46 ton, Kabupaten Pasuruan menyumbang kurang lebih $80 \%$ dari produksi ikan budi daya tambak tradisional plus (Badan Pusat Statistik [BPS] Jawa Timur, 2019, diolah tahun 2020). Kabupaten Pasuruan merupakan salah satu penyumbang terbesar produksi ikan budi daya tambak di Jawa Timur. Tentunya kontribusi produksi ikan tersebut berasal dari beberapa kecamatan yang ada di wilayah Pasuruan. Kecamatan Bangil merupakan kecamatan dengan rata-rata produksi ikan tambak tradisional plus terbanyak pada tahun 2018, dengan hasil produksi sebesar $2.597 .242 \mathrm{~kg} / \mathrm{ha}$ (Kabupaten Pasuruan, 2019, diolah tahun 2020). Hal ini menunjukkan bahwa potensi produksi ikan tambak tradisional plus di Kecamatan Bangil sangat baik.

Pengembangan komoditas unggulan daerah merupakan salah satu upaya yang dilakukan oleh pemerintah dalam pengembangan perekonomian daerah dengan melihat potensi pertanian yang dimiliki (Nguyen et al., 2019; Quach et al., 2017; Reggo et al., 2018). Komoditas unggulan yang dikembangkan merupakan komoditas yang memiliki keunggulan komparatif serta daya saing tinggi terhadap komoditas sejenis pada suatu daerah dibandingkan dengan daerah lain. Hal tersebut memberikan keuntungan dalam memenangkan persaingan di pasar, yang nantinya akan memberikan efek positif bagi penerimaan serta kesejahteraan masyarakat di daerah tersebut (Surahman \& Kusnadi, 2014). Komoditas tambak tradisional plus yang menjadi produk unggulan Kecamatan Bangil harus mendapat perhatian agar memberi dampak positif terhadap petambak tradisional plus di daerah ini. Hal ini dikarenakan hasil produksi ikan tambak tradisional plus di Kecamatan Bangil terbanyak dibandingkan kecamatan lainnya.

Produksi komoditas tambak tradisional plus yang melimpah tidak menjamin peningkatan pendapatan bagi tambak tradisional plus di Kecamatan Bangil. Peningkatan produksi tidak menjamin meningkatnya pendapatan petambak secara proporsional karena pendapatan petambak selain dipengaruhi oleh besarnya produksi juga dipengaruhi oleh sistem distribusi yang efisien, harga komoditas yang layak, dan kemampuan manajemen usaha (Nurwidyanti, 2005; Nguyen et al., 2017; Engle et al., 2017; Islam et al., 2016). Pendapatan petambak tradisional plus tidak hanya dipengaruhi oleh tingkat produktivitas dan sistem distribusi, tetapi juga kemampuan petambak dalam memasarkan hasil usaha taninya kepada konsumen dengan harga yang memadai juga sangat berpengaruh terhadap pendapatan petambak (Popoko, 2013). Perbaikan dalam bidang pemasaran diperlukan untuk memperbesar 
nilai yang diterima petambak dan memperkecil biaya pemasaran serta terciptanya jual dalam batas kemampuan daya beli konsumen (Ismail et al., 2008; Nasikh, 2014; Nasikh, 2016; Nasikh 2017a). Dalam rangka meningkatkan pendapatan petambak, diperlukan sistem distribusi komoditas tambak tradisional plus yang menguntungkan bagi petambak. Istilah efisiensi pemasaran sering digunakan dalam menilai prestasi kerja (performance) proses pemasaran. Hal tersebut mencerminkan konsensus bahwa pelaksanaan proses pemasaran harus berlangsung secara efisien (Jumiati et al., 2013). Apabila pemasaran yang ada sudah berjalan dengan efisien maka bisa meningkatkan kesejahteraan bagi semua pihak yang terlibat baik lembaga pemasaran maupun petambak sebagai produsen (Koestiono \& Agil, 2010; Al-Rouby et al., 2018; Mohammed, 2017; Nasikh, 2017b).

Usaha memperlancar arus barang/jasa dari produsen ke konsumen merupakan faktoryang tidak boleh diabaikan. Hal ini dapat dilakukan dengan memilih saluran distribusi yang tepat yang akan digunakan dalam rangka penyaluran barang/jasa dari produsen ke konsumen. Pada pendistribusian barang/jasa dari produsen ke konsumen terdapat pedagang perantara sehingga harga jual di pasar mengalami perubahan dari harga yang diberikan oleh petambak dengan harga yang diberikan pedagang di pasar atau terjadi kenaikan harga (Cristoporus \& Sulaeman, 2009). Petambak harus memilih pembeli yang paling menguntungkan untuk mengoptimalkan aktivitas perdagangan mereka (Putri et al., 2018). Rata-rata petambak akan menjual hasil panennya ke tengkulak atau pedagang pengumpul. Pedagang pengumpul mendistribusikan ikan yang dibeli dari petambak kepada pedagang besar. Pedagang pengumpul merupakan agen atau perwakilan pedagang besar. Pedagang besar tersebut mendistribusikan kepada pedagang pengecer untuk kemudian dijual kepada konsumen akhir. Proses yang panjang ini membuat share income yang didapat oleh petambak rendah dan mengurangi tingkat pendapatan petambak. Masalah pendistribusian ikan budi daya tersebut sangat penting dalam meningkatkan pendapatan petambak.

Dari pemaparan di atas, permasalahan kesejahteraan petambak tidak hanya terletak pada produksi tambak saja, ketidakefisienan distribusi juga mempengaruhi tingkat kesejahteraan petambak di Kabupaten Pasuruan. Oleh karena itu, penelitian ini dilakukan untuk menganalisis pola dan margin pemasaran petambak dalam rangka peningkatan kesejahteraan petambak, dengan studi kasus petambak tradisional plus di Kecamatan Bangil, Kabupaten Pasuruan.

Saluran pemasaran atau saluran distribusi merupakan serangkaian organisasi yang terkait dalam semua kegiatan yang digunakan untuk menyalurkan produk dan status kepemilikannya dari produsen kepada konsumen (Kotler \& Amstrong, 2010). Dengan demikian, dapat disimpulkan bahwa pengertian saluran distribusi adalah seperangkat organisasi yang saling tergantung, orang-orang yang terlibat di dalamnya melakukan proses perpindahan barang atau jasa yang telah tersedia untuk memenuhi kebutuhan konsumen.

Saluran pemasaran atau saluran distribusi mempunyai arti bahwa produsen dapat menggunakan lembaga atau perantara untuk dapat menyalurkan produknya kepada konsumen akhir. Sutrisno (2009) berpendapat bahwa lembaga pemasaran merupakan badanbadan yang menyelenggarakan kegiatan atau fungsi pemasaran. Lebih lanjut, menurut Sudiyono (2001), lembaga pemasaran adalah badan usaha atau individu yang menyelenggarakan pemasaran, menyalurkan barang dan jasa dari produsen kepada konsumen akhir, serta mempunyai hubungan dengan badan usaha atau badan usaha lainnya. Menurut Kotler dan Amstrong (2010), terdapat empat macam saluran distribusi: (1) Saluran tingkat nol (produsen-konsumen), disebut pula saluran pemasaran langsung, terdiri dari produsen yang menjual langsung kepada konsumen. Tiga cara penting dalam penjualan langsung adalah penjualan dari rumah ke rumah, penjualan lewat toko perusahaan; (2) Saluran tingkat satu (produsen-pengecer-konsumen), mempunyai satu perantara penjualan. Pada pasar konsumen, perantara itu sekaligus merupakan pengecer. Pada pasar industri sering kali ia bertindak sebagai agen penjualan atau makelar; (3) Saluran tingkat dua (produsen-grosir-pengecer-konsumen), mempunyai dua perantara penjualan. Pada pasar konsumen, mereka merupakan grosir atau pedagang besar dan sekaligus pengecer. Dalam pasar industri, mereka mungkin merupakan sebuah penyalur tunggal dan penyalur industri; serta (4) Saluran tingkat tiga (produsen-grosirdistributor-pengecer-konsumen), mempunyai tiga perantara penjualan. Masalah pengawasan semakin meningkat sesuai dengan angka tingkat saluran, walaupun biasanya produsen tersebut hanya berhubungan dengan saluran yang 
berdekatan dengannya.

Anindita (2003) mengemukakan bahwa pengertian nilai margin pemasaran adalah harga dari sekumpulan jasa pemasaran atau tata niaga yang merupakan hasil dari interaksi antara permintaan dan penawaran produk. Nilai margin pemasaran dibedakan menjadi dua, yaitu marketing costs dan marketing charges. Marketing costs merupakan biaya pemasaran yang terkait dengan tingkat pengembalian dari faktor produksi, sedangkan marketing charges berkaitan dengan berapa keuntungan yang diterima oleh pengolah, pengumpul, dan lembaga tata niaga lainnya. Menurut Sudiyono (2001), Ismail et al. (2008), dan Islam et al. (2016), margin pemasaran dapat didefinisikan dengan dua cara, yaitu: pertama, margin pemasaran merupakan perbedaan harga yang dibayarkan konsumen dengan harga yang diterima petambak; kedua, margin pemasaran merupakan biaya dari jasa-jasa pemasaran yang dibutuhkan sebagai akibat permintaan dan penawaran dari jasa-jasa pemasaran. Komponen margin pemasaran terdiri dari biaya yang dibutuhkan lembaga pemasaran untuk melakukan fungsifungsi pemasaran yang disebut biaya pemasaran dan keuntungan lembaga pemasaran.

Biaya pemasaran adalah biaya yang dikeluarkan untuk keperluan pemasaran (Sutrisno, 2009). Biaya pemasaran tersebut meliputi biaya angkut, biaya pengeringan, penyusutan, retribusi, dan lainnya. Besarnya biaya ini berbeda satu sama lain. Perbedaan disebabkan karena macam komoditas, lokasi pemasaran, dan macam lembaga pemasaran, serta efektivitas pemasaran yang dilakukan. Komoditas pertanian yang seringkali nilainya tinggi diikuti dengan biaya pemasaran yang tinggi pula. Peraturan pemasaran di suatu daerah terkadang juga berbeda satu sama lain. Begitu pula macam lembaga pemasaran dan efektivitas pemasaran yang mereka lakukan. Makin efektif pemasaran yang dilakukan, maka akan semakin kecil biaya pemasaran yang mereka keluarkan.

Dalam bidang perikanan, margin tata niaga menunjukkan selisih harga dari dua tingkat rantai pemasaran, yaitu perubahan harga antara harga petambak dan harga eceran (retail). Cara perhitungan ini sama dengan konsep nilai tambah (added alue) (Nasikh \& Hakim, 2015; Nasikh, 2013; Nasikh, 2017b). Ada tiga metode untuk menghitung margin pemasaran, yaitu dengan memilih dan mengikuti saluran pemasaran dari komoditas spesifik, membandingkan harga pada berbagai tingkat pemasaran yang berbeda, serta mengumpulkan data penjualan dan pembelian kotor tiap jenis pedagang (Anindita, 2003).

\section{Pendekatan IImiah}

Tambak tradisional plus merupakan lahan budi daya air payau yang dapat digunakan untuk budi daya komoditas air payau dengan menggunakan teknologi yang sederhana dan praktis bagi petambak serta mengedepankan nilai-nilai ekonomi hijau dan berkelanjutan untuk generasi sekarang maupun yang akan datang. Penelitian ini dilakukan kurang lebih selama 3 tahun, antara bulan Mei 2017 sampai bulan Agustus 2020 di Kawasan tambak budi daya air payau di Kecamatan Bangil, Kabupaten Pasuruan, Jawa Timur. Budi daya model tradisional plus telah dikembangkan oleh petambak di Kabupaten Pasuruan, Jawa Timur, yang didampingi oleh penyuluh dan tenaga perikanan dari UPT Budi Daya Air Payau dan Laut (BAPL) Dinas Kelautan dan Perikanan Provinsi Jawa Timur yang berlokasi di Desa Kalianyar, Kecamatan Bangil, Kabupaten Pasuruan, Jawa Timur. Lahan yang digunakan adalah lahan tambak tradisional plus yang disesuaikan dengan kondisi pengelolaan budi daya air payau selama ini. Komoditas budi daya air payau yang dibudidayakan adalah udang vaname, bandeng, nila, mujair, dan lain-lain (Badan Pusat Statistik [BPS] Kabupaten Pasuruan, 2019, data dianalisis tahun 2020).

Pendekatan yang digunakan dalam penelitian ini adalah deskriptif kualitatif (Ismail et al., 2008; Nasikh, 2014; Nasikh, 2016; Nasikh, 2017a), artinya penelitian ini menggambarkan atau menjelaskan suatu keadaan objek penelitian pada saat sekarang berdasarkan fakta-fakta yang tampak sebagaimana adanya. Prosedur ini digunakan untuk menyajikan data hasil penelitian dalam bentuk yang informatif agar mudah dipahami, dengan mencari proporsi (persentase) menggunakan distribusi frekuensi yang diperoleh berdasarkan data penelitian. Teknik pengambilan sampel pada penelitian ini melalui teknik snowball sampling, yaitu sebanyak 35 petambak, 8 pedagang pengumpul, 7 pedagang besar, dan 5 pedagang pengecer. Data yang telah terkumpul kemudian dianalisis secara deskriptif terhadap pola margin pemasaran dan kinerja pasar.

Analisis deskriptif digunakan untuk mengetahui pola margin pemasaran yang terjadi pada petambak tradisional plus di Kabupaten Pasuruan, Jawa Timur. 
Dalam pengolahan data, persentase diperoleh dengan formula (1) sebagai berikut (Anindita, 2003; Huda et al., 2015; Putri et al., 2018; Popoko, 2013).

$$
\mathrm{f}=\frac{f}{N} \times 100 \%
$$

Keterangan:

$\mathrm{f}=\quad=$ Frekuensi relatif/angka persentase

$f \quad=$ Frekuensi yang sedang dicari persentasenya

$\mathrm{N} \quad=$ Jumlah seluruh data

$100 \%=$ Konstanta

Analisis kinerja pasar dalam penelitian ini adalah analisis margin pemasaran dan share petambak. Dalam penelitian ini, margin pemasaran dihitung sebagai selisih antara harga jual komoditas usaha tambak tradisional plus di tingkat petambak dengan hargajual komoditas tambak tradisional plus di tingkat pengecer atau harga yang dikeluarkan konsumen. Nilai margin pemasaran dihitung dengan menggunakan formula (2) sebagai berikut (Huda et al., 2015; Putri et al., 2018; Popoko, 2013):

$$
\mathrm{MP}=\mathrm{Pf}-\mathrm{Pr}
$$

\section{Keterangan :}

$\mathrm{MP}=$ Margin pemasaran di lembaga pemasaran $(\mathrm{R} / \mathrm{pkg})$

$\mathrm{Pf}=$ Harga jual di tingkat petambak $(\mathrm{Rp} / \mathrm{kg})$

$\operatorname{Pr}=$ Harga beli di tingkat konsumen atau harga jual di tingkat pedagang paling akhir sebelum konsumen $(\mathrm{Rp} / \mathrm{kg})$

Dapat dihitung pula margin pemasaran pada setiap lembaga pemasaran dengan formula (3) sebagai berikut (Anindita, 2003; Huda et al., 2015; Putri et al., 2018; Popoko, 2013):

$$
\mathrm{MPi}=\mathrm{Ps}-\mathrm{Pb}
$$

$$
\begin{aligned}
& \text { Keterangan: } \\
& \mathrm{Mpi}= \text { Margin pemasaran pada lembaga pemasaran i } \\
&(\mathrm{Rp} / \mathrm{kg}) \\
& \mathrm{Ps}= \text { Harga jual pada lembaga pemasaran i }(\mathrm{Rp} / \mathrm{kg}) \\
& \mathrm{Pb}= \text { Harga beli pada lembaga pemasaran i }(\mathrm{Rp} / \mathrm{kg})
\end{aligned}
$$

Konsep pengukuran satuan dalam analisis ini adalah sebagai berikut:

1. Margin pemasaran dihitung berdasarkan perbedaan harga beli dengan harga jual dalam rupiah per kg komoditas;
2. Tingkat harga beli dihitung berdasarkan harga rata-rata pembelian per kg komoditas;

3. Tingkat harga jual dihitung berdasarkan harga rata-rata penjualan per $\mathrm{kg}$ komoditas.

Pola margin pemasaran pada tiap-tiap lembaga pemasaran dapat dihitung dengan menggunakan dengan formula (4) sebagai berikut (Anindita, 2003; Huda et al., 2015; Putri et al., 2018; Popoko, 2013):

DM : (Mi / Mtot) $\times 100$. Formula (4)

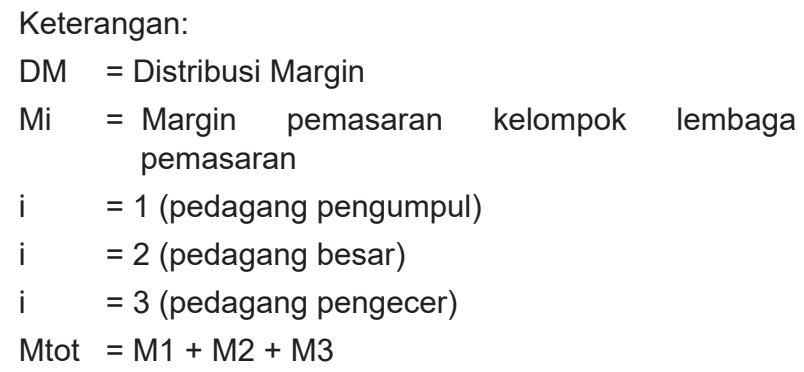

Share margin pemasaran dapat dihitung melalui formula (5) sebagai berikut (Anindita, 2003; Huda et al., 2015; Putri et al., 2018; Popoko, 2013):

$\mathrm{SMp}=\mathrm{MP} / \operatorname{Pr} \times 100 \%$ Formula (5)

Keterangan:

SMp = Share harga di tingkat lembaga pemasaran (\%)

$M P=$ Margin pemasaran $(\mathrm{Rp} / \mathrm{kg})$

$\operatorname{Pr} \quad=$ Harga di tingkat konsumen $(\mathrm{Rp} / \mathrm{kg})$

Analisis tentang share petambak bermanfaat untuk mengetahui bagian harga yang diterima oleh petambak dari harga di tingkat konsumen yang dinyatakan dalam persentase. Share petambak untuk komoditas tambak tradisional plus dapat dilihat pada formula (6) sebagai berikut (Anindita, 2003; Huda et al., 2015; Putri et al., 2018; Popoko, 2013).

$$
\mathrm{SPf}=\operatorname{Pf} / \operatorname{Pr} \times 100 \%
$$

\section{Keterangan :}

$\mathrm{SPf}=$ Share harga di tingkat petambak tradisional plus (\%)

$\mathrm{Pf}=$ Harga di tingkat petambak tradisional plus $(\mathrm{Rp} / \mathrm{kg})$

$\mathrm{Pr}=$ Harga di tingkat konsumen $(\mathrm{Rp} / \mathrm{kg})$

Efisien atau tidaknya alur distribusi dapat dilihat dari perbandingan antara share petambak 
dan share margin pemasaran. Apabila share petambak lebih besar dari share margin pemasaran, maka alur distribusi efisien. Sebaliknya, jika share petambak kurang dari share margin pemasaran maka alur distribusi tidak efisien. Selain itu, dapat dilihat juga distribusi share margin untuk setiap lembaga pemasaran merata atau tidak.

\section{POLADAN MARGIN PEMASARAN KOMODITAS TAMBAK TRADISIONAL PLUS}

Berdasarkan penelitian yang dilakukan dengan masing-masing pelaku distribusi komoditas tambak tradisional, hasil perhitungan analisis deskriptif, persentase mengenai pemilihan saluran distribusi komoditas tambak tradisional dapat ditampilkan pada Gambar 1.

Dari Gambar 1, dapat diperoleh lima pola margin pemasaran komoditas tambak tradisional plus oleh petambak, yaitu pertama, petambak ke pedagang pengumpul ke pedagang besar ke pedagang eceran ke konsumen; kedua, petambak ke pedagang pengumpul ke pedagang pengecer ke konsumen; ketiga, petambak ke pedagang besar ke pedagang pengecer ke konsumen; keempat, petambak ke pedagang pengumpul ke pedagang besar ke konsumen; kelima, petambak ke pedagang besar ke konsumen.

Sedangkan analisis kinerja pasar adalah sebagai berikut:

\section{Saluran Distribusi I}

(petambak—pedagang pengumpul—pedagang besar-pedagang eceran—konsumen)

Pada saluran I ini, pemasaran yang efisien adalah ikan nila dan udang vaname saja karena share yang didapat oleh petambak lebih besar daripada share yang diperoleh lembaga pemasaran. Pemasaran ikan bandeng dan ikan mujair tidak efisien karena share harga yang diterima petambak lebih sedikit dibandingkan yang didapat oleh lembaga pemasaran (Tabel 1).

Tabel 1. Perbandingan Share Margin Pemasaran dan Share Petambak pada Saluran I.

\begin{tabular}{lcccc}
\hline & \multicolumn{3}{c}{ Jenis Ikan/Udang } \\
\cline { 2 - 5 } & Bandeng & Nila & $\begin{array}{c}\text { Udang } \\
\text { Vaname }\end{array}$ & Mujair \\
\hline $\begin{array}{l}\text { Share } \\
\text { Margin }\end{array}$ & $53,23 \%$ & $41,27 \%$ & $34,36 \%$ & $56,52 \%$ \\
$\begin{array}{l}\text { Pemasaran } \\
\text { Share } \\
\text { Petambak }\end{array}$ & $46,769 \%$ & $58,73 \%$ & $65,641 \%$ & $43,478 \%$ \\
\hline
\end{tabular}

Sumber: Analisis Data Primer, 2021

\section{Saluran Distribusi II}

(petambak—pedagang pengumpul—pedagang eceran-konsumen)

Tabel 2. Perbandingan Share Margin Pemasaran dan Share Petambak pada Saluran II.

\begin{tabular}{lcccc}
\hline & \multicolumn{3}{c}{ Jenis Ikan/Udang } \\
\cline { 2 - 5 } & Bandeng & Nila & $\begin{array}{c}\text { Udang } \\
\text { Vaname }\end{array}$ & Mujair \\
\hline $\begin{array}{l}\text { Share } \\
\text { Margin }\end{array}$ & $26,67 \%$ & $25,93 \%$ & $11,76 \%$ & $40,00 \%$ \\
$\begin{array}{l}\text { Pemasaran } \\
\text { Share } \\
\text { Petambak }\end{array}$ & $73,33 \%$ & $74,07 \%$ & $88,23 \%$ & $60,00 \%$ \\
\hline
\end{tabular}

Sumber: Analisis Data Primer, 2021

Tabel 2 menunjukkan bahwa saluran II merupakan saluran pemasaran yang efisien karena share yang didapat oleh petambak lebih besar dari pada share yang diperoleh lembaga pemasaran.

\section{Saluran Distribusi III}

(petambak-pedagang besar-pedagang eceran- konsumen)

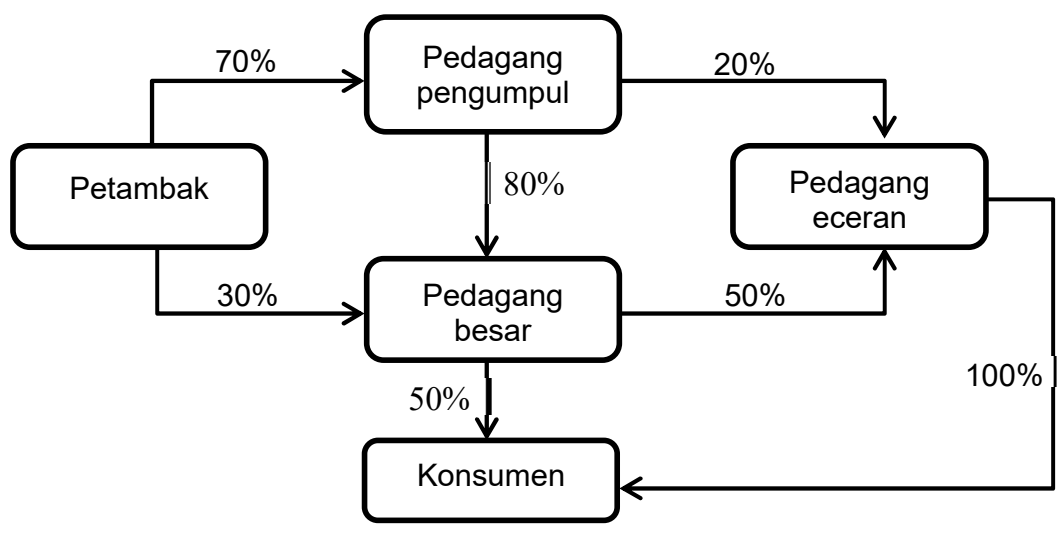

Gambar 1. Persentase Pemilihan Distribusi Komoditas Tambak Tradisional Plus Sumber: Data Primer Diolah, 2020 
Tabel 3. Perbandingan Share Margin Pemasaran dan Share Petambak pada Saluran III.

\begin{tabular}{lcccc}
\hline & \multicolumn{3}{c}{ Jenis Ikan/Udang } \\
\cline { 2 - 5 } & Bandeng & Nila & $\begin{array}{c}\text { Udang } \\
\text { Vaname }\end{array}$ & Mujair \\
\hline $\begin{array}{l}\text { Share } \\
\text { Margin }\end{array}$ & $48,00 \%$ & $37,037 \%$ & $22,963 \%$ & $32,50 \%$ \\
$\begin{array}{l}\text { Pemasaran } \\
\text { Share }\end{array}$ & $52,00 \%$ & $62,963 \%$ & $77,037 \%$ & $67,50 \%$ \\
Petambak & & & & \\
\hline
\end{tabular}

Sumber: Analisis Data Primer, 2021

Dapat diketahui bahwa pada Tabel 3, saluran III ini merupakan saluran pemasaran yang efisien karena share yang didapat oleh petambak lebih besar daripada share yang diperoleh lembaga pemasaran dan pembagiannya juga merata.

\section{Saluran Distribusi IV}

(petambak—pedagang pengumpul—pedagang besar- konsumen)

Tabel 4. Perbandingan Share Margin Pemasaran dan Share Petambak pada Saluran IV.

\begin{tabular}{|c|c|c|c|c|}
\hline & \multicolumn{4}{|c|}{ Jenis Ikan/Udang } \\
\hline & Bandeng & Nila & $\begin{array}{l}\text { Udang } \\
\text { Vaname }\end{array}$ & Mujair \\
\hline $\begin{array}{l}\text { Share } \\
\text { Margin } \\
\text { Pemasaran }\end{array}$ & $40,74 \%$ & & $18,02 \%$ & \\
\hline $\begin{array}{l}\text { Share } \\
\text { Petambak }\end{array}$ & $59,26 \%$ & & $81,98 \%$ & \\
\hline
\end{tabular}

Sumber: Analisis Data Primer, 2021

Berdasarkan Tabel 4, saluran IV ini cmerupakan saluran pemasaran yang efisien karena share yang didapat oleh petambak lebih besar daripada share yang diperoleh lembaga pemasaran. Namun, konsumen pada saluran ini merupakan perusahaan pengolah komoditas tambak tradisional plus yang akan diproduksi kembali. Harga beli yang dikeluarkan oleh perusahaan pengolah tersebut tidak sebesar yang dikeluarkan oleh konsumen biasa atau konsumen akhir. Oleh karena itu, bagian harga yang diperoleh petambak dan lembaga pemasaran pada saluran pemasaran ini lebih sedikit daripada saluran sebelumnya yang konsumennya merupakan konsumen akhir.

\section{Saluran Distribusi V}

(petambak—pedagang besar-konsumen)
Tabel 5. Perbandingan Share Margin Pemasaran dan Share Petambak Saluran V.

\begin{tabular}{|c|c|c|c|c|}
\hline & \multicolumn{4}{|c|}{ Jenis Ikan/Udang } \\
\hline & Bandeng & Nila & $\begin{array}{c}\text { Udang } \\
\text { Vaname }\end{array}$ & Mujair \\
\hline $\begin{array}{l}\text { Share } \\
\text { Margin } \\
\text { Pemasaran }\end{array}$ & $12,76 \%$ & & $4,80 \%$ & \\
\hline $\begin{array}{l}\text { Share } \\
\text { Petambak }\end{array}$ & $78,33 \%$ & & $99,21 \%$ & \\
\hline
\end{tabular}

Sumber: Analisis Data Primer, 2021

Berdasarkan Tabel 5, nampak bahwa saluran $\mathrm{V}$ ini merupakan saluran pemasaran yang efisien karena share yang didapat oleh petambak lebih besar daripada share yang diperoleh lembaga pemasaran. Namun, pembagian harga terlalu jauh untuk yang diterima petambak dan yang diterima oleh lembaga pemasaran.

\section{POLA DISTRIBUSI KOMODITAS TAMBAK TRADISIONAL PLUS}

Berdasarkan data yang diperoleh dan hasil analisis deskriptif di atas, komoditas usaha tambak tradisional plus dari petambak hingga ke tangan konsumen ada beberapa pilihan alternatif. Dari petambak, komoditas tambak tradisional plus dapat langsung dijual ke pedagang besar atau melalui tangan pedagang pengepul terlebih dahulu. Biasanya petambak yang langsung menjual ke pedagang besar memiliki kendaraan sendiri untuk mengangkut hasil produksi tambak dari lahan tambak menuju pasar ikan. Petambak sangat mungkin merangkap menjadi pedagang pengumpul di desanya masing-masing. Petambak yang menjual ikannya melalui pedagang pengumpul, akan mendapatkan pemasaran yang lebih mudah dan efisien. Selama ini, sebagian besar petambak kurang ahli dalam bidang pemasaran, yang berdampak kualitas ikan akan menurun (komoditas ikannya sudah tidak segar lagi). Hal ini sejalan dengan penelitian yang dilakukan oleh Sari (2017).

Pedagang pengumpul kemudian langsung bisa menjual ke pedagang eceran ataupun pedagang besar. Hasil poduksi tambak yang sudah dimuat oleh pedagang pengumpul akan diangkut ke pasar ikan Kalirejo Bangil dan dibongkar, kemudian ditimbang kembali. Setelah ada kesepakatan harga yang sesuai dengan harga pasar saat itu, akan dilakukan pembayaran. Ketika pedagang pengumpul menjual ke pedagang pengecer, biasanya mereka memiliki pelanggan tetap, jika tidak maka kemungkinan ikan tidak 
habis (masih tersisa) dan ikan akan busuk jika dibiarkan lama. Distribusi barang dari pedagang pengumpul ke pedagang besar, setelah proses penimbangan dan pembayaran, ikan akan disimpan di gudang beberapa jam untuk kemudian diangkut ke luar kota.

Komoditas tambak dari pedagang besar ada yang dijual ke pedagang eceran dan ada pula yang langsung dijual ke konsumen. Konsumen yang dituju langsung pedagang besar adalah industri pengolah ikan dan udang yang membutuhkan komoditas tersebut sebagai bahan baku produksi. Pedagang besar yang menjual ikan di pasar yang lebih besar (misalnya di pasar Pabean), komoditas tersebut akan dibeli oleh pedagang pengecer dari kota-kota besar di Jawa Timur, misalnya Surabaya, Malang, Jombang, Mojokerto, dan sekitarnya. Biasanya mereka juga sudah mempunyai langganan tersendiri. Barang yang berasal dari pedagang eceran akan disalurkan semuanya ke konsumen. Kebanyakan pedagang eceran membeli dalam volume kecil karena ikan yang tidak laku akan membusuk dan pedagang harus bersiap mendapat kerugian.

Dari analisis tersebut, dapat diperoleh lima pola alur distribusi komoditas tambak tradisional plus, yaitu: pertama, petambak ke pedagang pengumpul ke pedagang besar ke pedagang eceran ke konsumen; kedua, petambak ke pedagang pengumpul ke pedagang pengecer ke konsumen; ketiga, petambak ke pedagang besar ke pedagang pengecer ke konsumen; keempat, petambak ke pedagang pengumpul ke pedagang besar ke konsumen; kelima, petambak ke pedagang besar ke konsumen. Hasil analisis dan kajian ini sama dengan penelitian yang dilakukan oleh Amalia et al., 2013.

\section{MARGIN PEMASARAN KOMODITAS TAMBAK TRADISIONALPLUSDIKABUPATEN PASURUAN}

Dari analisis dan kajian di atas, saluran distribusi ini merupakan saluran distribusi yang paling panjang, tetapi juga menjadi saluran distribusi yang paling banyak diterapkan oleh petambak dan lembaga pemasaran (Hartoyo \& Fariyanti, 2018; Mizuta \& Vlachopoulou, 2017). Analisis margin pemasaran ini mampu mengetahui pendapatan yang diperoleh setiap lembaga pemasaran pada setiap kilogram ikan. Namun, angka yang didapatkan dari hasil analisis pada tulisan ini belum dikurangi oleh biaya pemasaran. Pada saluran I, margin pemasaran paling besar terdapat pada udang vaname, kemudian ikan bandeng, dan ikan mujair. Margin pemasaran yang paling kecil adalah pada jenis ikan. Pada saluran distribusi ini, pelaku utama yang memperoleh margin pemasaran paling banyak adalah pedagang eceran kemudian pedagang pengumpul. Pelaku utama yang memperoleh margin pemasaran paling kecil adalah pedagang besar.

Distribusi margin pemasaran menunjukkan besar margin tiap-tiap lembaga pemasaran dalam bentuk persentase. Pelaku usaha yang memperoleh distribusi margin pemasaran paling banyak adalah pedagang eceran. Meskipun distribusi margin pemasaran yang didapatkan oleh pedagang eceran adalah yang terbanyak, nilai pendapatan yang diperoleh pedagang eceran masih sedikit. Hal tersebut dikarenakan pedagang eceran menjual ikan dengan volume yang lebih sedikit. Keuntungan yang didapat oleh pedagang eceran per kilogram ikan juga banyak namun tidak seberapa bila dikalikan dengan volume penjualan yang hanya beberapa kilogram dalam sekali penjualan. Keuntungan yang diperoleh pedagang pengumpul dan pedagang besar jauh lebih besar jika dibandingkan dengan pedagang pengecer. Share yang diperoleh petambak pada saluran distribusi ini hanya ikan nila dan udang vaname saja yang lebih dari $50 \%$.

Dari analisis margin pemasaran dan share petambak dapat diketahui bahwa pada saluran I, pemasaran yang efisien adalah ikan nila dan udang vaname saja, karena share yang didapat oleh petambak lebih besar daripada share yang diperoleh lembaga pemasaran. Pemasaran ikan bandeng dan ikan mujair tidak efisien karena share harga yang diterima petambak lebih sedikit dibandingkan yang didapat oleh petambak. Selain itu, biaya pemasaran juga semakin tinggi. Hal ini sejalan dengan penelitian yang dilakukan oleh Takalamingan et al., 2017 dan Huda et al., 2015.

Pada saluran distribusi II terdapat 15 sampel petambak, 4 sampel pedagang pengumpul, dan 3 sampel pedagang eceran. Pada saluran II, margin pemasaran paling besar terdapat pada jenis ikan mujair, kemudian ikan nila, dan ikan bandeng. Margin pemasaran yang paling kecil adalah jenis udang vaname. Margin pemasaran paling banyak diperoleh pedagang eceran, kemudian pedagang pengumpul. Sama halnya dengan saluran I, pedangan eceran memperoleh margin 
pemasaran paling banyak, tetapi pendapatan yang diperoleh pedagang eceran masih sedikit. Hal ini dikarenakan pedagang eceran menjual ikan dengan volume yang sedikit sehingga biaya yang dikeluarkan oleh pedagang pun banyak jika dibagi dengan volume penjualan. Keuntungan yang didapat oleh pedagang eceran per kilogram ikan juga banyak namun tidak seberapa bila dikalikan dengan volume penjualan yang hanya beberapa kilogram dalam sekali berdagang. Keuntungan yang diperoleh pedagang pengumpul jauh lebih besar jika dibandingkan dengan pedagang pengecer. Share petambak yang diperoleh pada saluran distribusi ini lebih dari $50 \%$.

Dari analisis margin pemasaran dan share petambak dapat diketahui bahwa saluran II merupakan saluran pemasaran yang efisien karena share yang didapat oleh petambak lebih besar daripada share yang diperoleh lembaga pemasaran. Walaupun demikian, margin pemasaran dari lima pola yang ada belum menunjukkan margin pemasaran yang merata bagi produsen/petambak (Tabel 1, Tabel 2, Tabel 3, Tabel 4, dan Tabel 5).

Pada saluran distribusi III terdapat 13 sampel petambak, 3 sampel pedagang besar, dan 2 sampel pedagang eceran. Pada saluran III, margin pemasaran paling besar terdapat pada jenis ikan bandeng, kemudian udang vaname, dan ikan nila. Margin pemasaran yang paling kecil adalah jenis ikan mujair. Margin pemasaran paling banyak diperoleh pedagang eceran kemudian pedagang pengumpul. Sama halnya dengan saluran I, saluran II, dan penelitian yang dilakukan oleh Anita et al. (2012), pedagang eceran memperoleh margin pemasaran paling banyak, tetapi pendapatan yang diperoleh pedagang eceran masih sedikit. Hal ini dikarenakan pedagang eceran menjual ikan dengan volume yang sedikit sehingga biaya yang dikeluarkan oleh pedagang pun banyak jika dibagi dengan volume penjualan. Keuntungan yang didapat oleh pedagang eceran per kilogram ikan juga banyak, tetapi hasilnya masih kecil bila dikalikan dengan volume penjualan yang kecil dalam sekali berdagang. Keuntungan yang diperoleh pedagang besar jauh lebih besar jika dibandingkan dengan pedagang pengecer. Share petambak yang diperoleh petambak pada saluran distribusi ini semua lebih dari $50 \%$ serta share margin pemasaran terbilang merata dan tidak merugikan petambak.

Berdasarkan analisis margin pemasaran dan share petambak dapat diketahui bahwa saluran
III merupakan saluran pemasaran yang efisien karena share yang didapat oleh petambak lebih besar daripada share yang diperoleh lembaga pemasaran dan pembagiannya juga merata.

Pada saluran distribusi IV, terdapat 5 sampel petambak, 2 sampel pedagang pengumpul, dan 2 sampel pedagang besar. Pada saluran pemasaran IV ini, pedagang besar menjual ke konsumen yang merupakan perusahaan pengolahan, sedangkan ikan yang dijual oleh pedagang tersebut hanya ikan bandeng dan udang vaname saja, karena yang dibutuhkan perusahaan pengolah hanya keduajenis ikan tersebut. Pada saluran IV, margin pemasaran paling besar terdapat pada jenis ikan bandeng dan margin pemasaran yang paling kecil adalah jenis udang vaname. Pada saluran distribusi ini, margin pemasaran paling banyak diperoleh pedagang pengumpul kemudian pedagang besar. Berbeda dengan saluran lainnya, pedagang pengumpul memperoleh margin pemasaran paling banyak, tetapi pendapatan yang diperoleh lebih sedikit dibanding dengan pendapatan yang diperoleh pedagang besar pada saluran pemasaran ini. Hal ini dikarenakan pedagang pengumpul menjual ikan dengan volume yang lebih sedikit daripada volume penjualan pedagang besar. Share petambak yang diperoleh petambak pada saluran distribusi ini semua lebih dari $50 \%$.

Berdasarkan analisis margin pemasaran dan share petambak dapat diketahui bahwa saluran IV merupakan saluran pemasaran yang efisien karena share yang didapat oleh petambak lebih besar daripada share yang diperoleh lembaga pemasaran. Namun, konsumen pada saluran ini merupakan perusahaan pengolah tempat ikan-ikan tersebut akan diproduksi kembali sehingga harga beli yang dikeluarkan oleh perusahaan pengolah tidak sebesar yang dikeluarkan oleh konsumen biasa atau konsumen akhir. Oleh karena itu, bagian harga yang diperoleh petambak dan lembaga pemasaran pada saluran pemasaran ini lebih sedikit daripada saluran sebelumnya yang konsumennya merupakan konsumen akhir (Allen et al., 2019; Prosperi et al., 2019; Mizuta \& Vlachopoulou, 2017).

Saluran distribusi IV merupakan alur distribusi terpendek. Pada saluran distribusi ini terdapat 6 sampel petambak dan 1 sampel pedagang besar. Seperti halnya saluran IV, pada saluran pemasaran $\mathrm{V}$, pedagang besar menjual ke konsumen yang merupakan perusahaan pengolahan. Pedagang tersebut hanya menjual 
ikan bandeng dan udang vaname sesuai dengan kebutuhan perusahaan pengolah. Melalui margin pemasaran ini dapat kita ketahui pendapatan yang diperoleh lembaga pemasaran pada setiap kilogram ikan, namun angka tersebut belum dikurangi biaya pemasaran.

Pedagang besar menjadi satu-satunya lembaga pemasaran dalam saluran ini, tetapi mereka tidak mengambil banyak keuntungan pada setiap kilogram ikan karena tingginya harga yang ditawar petambak atau rendahnya harga permintaan dari konsumen yang pada kasus ini merupakan perusahaan pengolah. Saluran $V$ merupakan saluran pemasaran yang efisien karena share yang didapat petambak lebih besar dari pada share yang diperoleh lembaga pemasaran. Namun, pembagian pendapatan yang diterima petambak dengan yang diterima oleh lembaga pemasaran tidaklah sama. Bentuk saluran dalam penelitian ini merupakan share income yang diperoleh dari petambak paling tinggi dibanding dengan pelaku ekonomi lainnya. Hal tersebut sejalan dengan penelitian yang dilakukan oleh Putri et al. (2018) yang menyebutkan bahwa produsen (penghasil komoditas) sebagai pelaku pertama dalam pola saluran distribusi mampu memperoleh share income yang lebih tinggi dibanding pelaku pemasaran lainnya. Ini artinya, penghasil komoditas, dalam hal ini petambak, memperoleh share income yang lebih besar dibandingkan pelaku ekonomi lainnya.

Semakin panjang saluran pemasaran, maka bagian harga yang diterima petambak semakin kecil, walaupun harga yang dibayarkan konsumen semakin besar. Perbedaan share petambak yang terjadi pada setiap saluran pemasaran dikarenakan adanya perbedaan harga yang diterima setiap lembaga pemasaran, jumlah lembaga pemasaran yang terlibat serta fungsifungsi yang dilakukan sehingga meningkatkan harga di tingkat konsumen (Nguyen \& Jolly, 2017). Hal ini diperkuat dengan penelitian yang dilakukan oleh Situmorang (2015). Nilai margin suatu saluran pemasaran selain dipengaruhi oleh panjang pendeknya saluran pemasaran, aktivitas pemasaran yang dilaksanakan, dan keuntungan yang diharapkan oleh lembaga pemasaran yang terlibat, juga dipengaruhi oleh kualitas produk yang diperdagangkan. Hal tersebut sejalan dengan penelitian yang dilakukan oleh Baladina (2008); Allen et al. (2019); Al-Rouby, et al. (2018); Engle, et al. (2017); Huda, et al. (2015).

\section{PENUTUP}

Hasil penelitian ini menunjukkan ada lima pola distribusi komoditas tambak tradisional plus, yaitu: pertama, petambak ke pedagang pengumpul ke pedagang besar ke pedagang eceran ke konsumen; kedua, petambak ke pedagang pengumpul ke pedagang pengecer ke konsumen; ketiga, petambak ke pedagang besar ke pedagang pengecer ke konsumen; keempat, petambak ke pedagang pengumpul ke pedagang besar ke konsumen; serta kelima, petambak ke pedagang besar ke konsumen. Margin pemasaran komoditas tambak tradisional plus telah memberikan keberpihakan pada petambak. Margin pemasaran pola ketiga memberikan efisiensi bagi petambak karena jalur pemasaran yang cukup pendek dan tidak mengurangi pendapatan petambak. Oleh karena itu, penerimaan pendapatan petambak lebih menguntungkan dibandingkan dengan pola margin pemasaran lainnya.

\section{UCAPAN TERIMA KASIH}

Pada kesempatan ini penulis mengucapkan terima kasih atas bantuan dana dan fasilitas Direktorat Riset dan Pengabdian Kepada Masyarakat (DRPM), Kementerian Pendidikan dan Kebudayaan Rl; Lembaga Penelitian dan Pengabdian kepada Masyarakat (LP2M), Fakultas Ekonomi, dan Fakultas IImu Sosial Universitas Negeri Malang (UM); Universiti Technology Malaysia (UTM) Malaysia; para informan yang telah memberikan sejumlah data yang dibutuhkan dalam penelitian ini; UPT BAPL Bangil Kabupaten Pasuruan, Provinsi Jawa Timur; serta Kementerian Kelautan dan Perikanan Republik Indonesia.

\section{PERNYATAAN KONTRIBUSI PENULIS}

Nasikh merupakan Kontributor Utama sebagai peneliti di bidang sosial ekonomi pertanian dan perikanan yang merancang model penelitian kuantitatif deskripsi ini; Hadi Sumarsono, Joko Sayono, Mohd Al-ikhsan Ghazali sebagai Kontributor Anggota untuk menganalisis data penelitian. Yunani dan Lely Jayanti merupakan Kontributor Anggota membantu pengumpulan data di lapangan.

\section{DAFTAR PUSTAKA}

Allen, T., Prosperi, P., Cogill, B., Padilla, M., \& Peri, I. (2019). A delphi approach to develop sustainable food system metrics. Soc Indic Res, 141, 1307-1339. https://doi.org/10.1007/s11205018-1865-8 
Al-Rouby, I. T. H. A. J., Al-Sayed, S. M., \& Darwish, M. A. (2018). The economics of production of fish farms in Fayoum Governorate. Journal of the Saudi Society for Agricultural Sciences, 17(2A), 39-66.

Amalia, D. N., Nurmalina, R., \& Rifin, A. (2013). Sistem pemasaran karet rakyat di Provinsi Jambi dengan pendekatan struktur, perilaku, dan kinerja pasar. Buletin RISTRI, 4(3), 237-244.

Anindita, R. (2003). Dasar-dasar pemasaran hasil pertanian. Universitas Brawijaya.

Anita, Muani, A., \& Suyatno, A. (2012). Analisis efisiensi pemasaran jeruk siam di Kecamatan Tebas Kabupaten Sambas. Jurnal Sains Mahasiswa Pertanian, 1(1), 22-31. https://jurnal.untan. ac.id/index.php/jspp/article/view/546

Badan Pusat Statistik [BPS] Jawa Timur. (2019). Provinsi Jawa Timur dalam angka 2019. Badan Pusat Statistik. https:// jatim.bps.go.id/publication/2019/08/16/ f668b9b7ca53a7998bc81453/provinsi-jawa-timur-dalam-angka-2019

Badan Pusat Statistik [BPS] Kabupaten Pasuruan. Statistik daerah Kabupaten Pasuruan 2019. Badan Pusat Statistik. https:// pasuruankab.bps.go.id/publication/2019/11/25/ d572dde39c0f3d24419ae7af/statistik-daerah-kabupaten-pasuruan-2019.html

Baladina, N. (2008). Analisis struktur, perilaku, dan penampilan pasar wortel di Sub Terminal Agrobisnis (Sta) Mantung (Kasus pada Sentra Produksi Wortel di Desa Tawangsari, Kecamatan Pujon, Kabupaten Malang). AGRISE, XII(2), 91-104.

Indonesia Climate Change Trust Fund [ICCTF]. (2020, 9 Oktober). Memaknai Kebijakan Presisi Perikanan. ICCTF. https://www.icctf.or.id/memaknai-kebijakan-presisi-perikanan/

Cristoporus, \& Sulaeman. (2009). Analisis produksi dan pemasaran jagung di Desa Labuan Toposo Kecamatan Tawaeli Kabupaten Donggala. Jurnal Agroland, 16(2), 141-147.

Koestiono, D., Agil, A. (2010). Marketing efficiency analysis of sweet orange. Jurnal AGRISE, X(1), 26-38.

Engle, C. R., McNevin, A., Racine, P., Boyd, C. E., Paungkaew, D., Viriyatum, R., Tinh, H. Q., \& Minh, H. N. (2017). Economics of sustainable intensification of aquaculture: Evidence from shrimp farms in Vietnam and Thailand. Journal of the World Aquaculture Society, 48(2). https:// doi.org/10.1111/jwas.12423

Hartoyo, K.L. and Fariyanti, A. (2018). Risk and improvement strategy of vannamei shrimp production in the Blanakan sub-district Subang Regency. Jurnal Sosial Ekonomi Kelautan dan Perikanan, 13(1), 99-110. http://dx.doi. org/10.15578/jsekp.v13i1.6764
Huda, M., Solihin, I., \& Lubi, E. (2015). Tingkat efisien pemasaran ikan laut segar di Pelabuhan Perikanan Nusantara Brondong. Jurnal Teknologi Perikanan dan Kelautan, 6(1), 91-104. https:// doi.org/10.24319/jtpk.6.91-104

Islam, G. M. N., Tai, S. Y., \& Kusairi, M. N. (2016). A stochastic frontier analysis of technical efficiency of fish cage culture in Peninsular Malaysia. SpringerPlus 5, 1127. https://doi.org/10.1186/ s40064-016-2775-3

Ismail, G., Supardi, S., and Wahyuningsih, S., M. J. (2008). Anaysis efficiency marketing system of fresh layang fish (Decapterus russeli) on Pelabuhan Fish Auction Place in Tegal City. Jurnal IImu-ilmu Pertanian Mediagro, 4(2), 39-50. http://dx.doi. org/10.31942/md.v4i2.555

Jayanti, L. (2020). Analisis struktur pasar dan kesejahteraan petani ikan di Kecamatan Bangil Kabupaten Pasuruan [Skripsi, UM].

Jumiati, E., Darwanto, D. H., Hartono, S., \& Masyhuri. (2013). Analisis saluran pemasaran dan margin pemasaran kelapa dalam di daerah perbatasan Kalimantan Timur. Jurnal AGRIFOR, 12(1), 1-10. https://doi.org/10.31293/af.v12i1.165

Kotler, P., \& Armstrong, G. (2010). Dasar-dasar pemasaran (Jilid 1) (A. Sindoro, Alih Bahasa; B. Molan, Ed.). Prenhallindo.

Mohammed, S. M. (2017). An economic study to assess the expected and expected production and consumption of fish in Egypt. Journal of Agricultural Economics and Social Sciences, Faculty of Agriculture, 8(2), 123-128. https:// dx.doi.org/10.21608/jaess.2017.36457

Mizuta, D. D., \& Vlachopoulou, E. I. (2017). Satoumi concept illustrated by sustainable bottom-up initiatives of Japanese Fisheries Cooperative Associations. Marine Policy 78, 143-149. https:// doi.org/10.1016/j.marpol.2017.01.020

Nasikh. (2013). A model of collaborative forest resources management to improve the prosperity of poor family farmers in East Java. The Indonesian Journal of Geography, 45(1), 80-89. https://doi. org/10.22146/ijg.2408

Nasikh. (2014). Horizontal management of forest resources to enhance the partnership and account ability in Pasuruan, East Java, Indonesia. Asian Journal of Humanities and Social Studies, 2(5), 685-688. https://www.ajouronline.com/index. php/AJHSS/article/view/1591

Nasikh. (2016). Developing ecotourism as an attempt to improve the competitiveness in the economic globalization era in Banyuwangi regency, East Java Province. IJER Serials Publication, 13(7), 2735-2750.

Nasikh. (2017a). An analysis of factors affecting Indonesian's economic growth. International 
Business Management, 11(3), 802-806. http:// dx.doi.org/10.36478/ibm.2017.802.806

Nasikh. (2017b). Institutional model and activities of destitute society around forest as an attempt to develop the sustainable and equitable forest in East Java. Indonesia. Periodica Polytechnica Social and Management Sciences, 25(1). 8-16. https://doi.org/10.3311/PPso.8536

Nasikh, Hakim, L. M. (2015). The regional government policy to maintain the East Java food security to achieve the imported rice-free. Joint Research of Balitbang of East Java Province and the State University of Malang. Research Finding Report.

Nguyen, L. A., Bosma, R., Verreth, J., Leemans, R., De Silva, S., \& Lansink, A. O. (2018). Impact of climate change on the technical efficiency of striped catfish, Pangasianodon hypophthalmus, farming in the Mekong Delta, Vietnam. Journal of the World Aquaculture Society, 49, 570-581.

Nguyen, T. A. T., Nguyen, K. A. T., \& Jolly, C, M. (2019) Is super-intensification the solution to shrimp production and export sustainability? Sustainability, MDPI, Open Access Journal, 11(19), $1-22$.

Nguyen, T. A. T., Bui, C. T. P. N., \& Jolly, C. M. (2017) The value chain of exported whiteleg shrimp: Case study in Khanh Hoa Province, Vietnam. International Journal of Food and Agricultural Economics (IJFAEC), 5(2), 9-23. https://doi. org/10.22004/ag.econ.266468

Nguyen, T. A. T., \& Jolly, C. M. (2017). Macro-economic and product challenges facing Vietnamese the Pangasius Industry. Reviews in Fisheries Science \& Aquaculture, 26(2), 183-194. https://doi.org/1 $0.1080 / 23308249.2017 .1379948$

Nurwidyanti, M. (2005). Analisis penampilan pasar pada pemasaran ikan bandeng (Studi kasus di Kecamatan Sindang, Kabupaten Indramayu). Seminar Hasil Pertanian (Buku 2: Pemasaran). Program Pascasarjana UB.

Pemerintah Kabupaten Pasuruan. (2020, 22 Januari). Perikanan budidaya. https://www.pasuruankab. go.id/potensi-188-perikanan-budidaya-.html

Phillips, M., Henriksson, P. J. G., Tran, N. V., Chan, C. Y., Mohan, C. V., Rodriguez, U., Suri, S., Hall, S, Koeshendrajana, S. (2016). Menjelajahi masa depan perikanan budidaya Indonesia. WorldFish. Laporan Program: 2016-02.

Popoko, S. (2013). Pengaruh biaya pemasaran terhadap tingkat pendapatan petani kopra di Kecamatan Tobelo Selatan Kabupaten Halmahera Utara. Jurnal UNIERA, 2(2). 80—91.

Prosperi, P., Kirwan, J., Maye, D., Bartolini, F., Vergamini, D., Brunori, G. (2019). Adaptation strategies of small-scale fisheries within changing market and regulatory conditions in the EU. Marine
Policy, 100, 316-323. https://doi.org/10.1016/j. marpol.2018.12.006

Putri, R. K., Nurmalina, R., \& Burhanuddin, B. (2018). Analisis efisiensi dan faktor yang memengaruhi pilihan saluran pemasaran. Jurnal IImiah Manajemen, Volume VIII(1), 109-135. https:// dx.doi.org/10.22441/mix.2018.v8i1.007

Quach, A., Murray, F., \& Morrison-Saunders, A. (2017). The vulnerability of shrimp farming income to climate change events: A case study in $\mathrm{Ca} \mathrm{Mau}$, Vietnam. International Journal of Climate Change Strategies and Management, 9(2), 261-280. https://doi.org/10.1108/IJCCSM-05-2015-0062

Reggo, M. A. S., Sabba, J. O., Soares, R. B., \& Peixoto, S. (2018). Technical efficiency analysis of marine shrimp farming (Litopenaeus vannamei) in biofloc and conventional systems: A case study in Northeastern Brazil. An Acad Bras Cienc, 90(4), 3705-3716. https://doi.org/10.1590/00013765201820170953

Sari, A. I. (2017). Efisiensi pemasaran melalui minimasi jalur distribusi susu segar sapi perah di Kecamatan Mojosongo Kabupaten Boyolali. Caraka Tani: Journal of Sustainable Agriculture, 32(1), 42-48. https://doi.org/10.20961/carakatani.v32i1.15082

Situmorang, T. S. (2015). Analisis efisiensi pemasaran sawi manis dengan pendekatan structure, conduct, and performance (SCP) di Kecamatan Jambi Selatan Kota Jambi. Jurnal Sosio Ekonomika Bisnis, 18(2), 79-89. https://doi. org/10.22437/jiseb.v18i2.2830

Sudiyono, A. (2001). Pemasaran pertanian. Universitas Muhamadyah Malang.

Surahman, T., \& Kusnadi, N. (2014). Sistem pemasaran nenas bogor (Ananas comosus) di Kabupaten Bogor. CR Journal, 2(1), 69-82. http://dx.doi. org/10.34147/crj.v2i1.14

Sutrisno. (2009). Upaya peningkatan pendapatan petani melalui pemasaran beras. Kantor Penelitian dan Pengembangan Kabupaten Pati.

Takalamingan, M., Longdong, F. V., \& Jusuf, A. (2017). Analisis efisiensi saluran distribusi dan risiko pelaku usaha pada rantai pasok ikan cakalang asap di Kelurahan Girian Atas Kota Bitung Provinsi Sulawesi Utara. AKULTURASI: Jurnal IImiah Agrobisnis Perikanan, 5(9). 705-712. https://doi. org/10.35800/akulturasi.5.9.2017.16996 